\title{
Metal enhanced fluorescence of thiacyanine dye in layered polymer films
}

\author{
N.V.Pereverzev, I.A.Borovoy, O.O.Sedyh, \\ S.L.Yefimova, A.V.Sorokin

\begin{abstract}
Institute for Scintillation Materials, STC "Institute for Single Crystals", National Academy of Sciences of Ukraine, 60 Lenin Ave., 61001 Kharkiv, Ukraine
\end{abstract}

\section{Received September 20, 2014}

\begin{abstract}
The metal enhanced fluorescence of thiacyanine dye monomers in polymer films has been studied. To control the distance between dye molecules and silver nanoparticles a polymer spacer has been used. The spacer thickness has been varied using a layer-by-layer assembly method of polyelectrolytes. The best 4.5 times fluorescence enhancement has been observed for the $20 \mathrm{~nm}$ thick polymer spacer. The result has been confirmed both by steady-state and time-resolved fluorescence spectroscopies.
\end{abstract}

\footnotetext{
Изучено усиление флуоресценции мономеров цианинового красителя металлическими наночастицами в полимерных пленках. Для контроля расстояния между молекулами красителя и наночастицами серебра использовалась полимерная прослойка. Толщина прослойки варьировалась методом послойной сборки полиэлектролитов. Максимальное усиление флуоресценции в 4.5 раза наблюдалось при толщине полимерной прослойки 20 нм. Данный результат подтвержден при помощи как стационарной, так и время-разрешенной флуоресцентной спектроскопии.
}

Флуоресценція ціанінового барвника посилена металевими наночастинками у шаруватих полімерних плівках. М.В.Переверзєв, І.А.Боровой, О.О.Сєдих, С.Л.Єфімова, О.В.Сорокін.

Досліджено посилення флуоресценції мономерів ціанінового барвника металевими наночастинками у полімерних плівках. Для контролю відстані між молекулами барвника і наночастинками срібла використовували полімерний прошарок. Товщина прошарку змінювалася за методом пошарової збірки поліелектролітів. Максимальне посилення флуоресценції у 4.5 рази спостерігалося при товщині полімерного прошарку 20 нм. Даний результат підтверджено за допомогою як стаціонарної, так і розділеної за часом флуоресцентної спектроскопії.

\section{Introduction}

Nanoplasmonics is the novel field of physics which deal with optical phenomena in or near metal nanoparticles (NPs) [1-3]. Due to metal nanoparticles interaction with an incident electric wave the later causes displacement of free electrons with respect to the NPs lattice resulting in so called localized surface plasmon (LSP) resonances appearing. If frequency of an excitation light wave is close to that of LSP strongly enhanced local electric field is appeared near the NP surface in a subwavelength region [1-3]. One of the important consequences of such phenomenon is a significant enhancement of fluorescence of optical species by the localized electric field in proximity of metal NPs known as metal-enhanced fluorescence (MEF) or plasmon-enhanced fluorescence (PEF) [4-9]. Since the NPs local electric field affects both radiative and nonradiative decay rates, MEF effectiveness appeared to be a distance dependent. Besides, fluorescence enhancement coefficient dependends on intrinsic fluorophore charac- 
teristics such as an absorption cross-section, fluorescence quantum yield, lifetime and so on [4-6]. So, MEF should be studied carefully on the case specific basis.

Recently, we have reported MEF effects on thiacyanine dye $J$-aggregates in water solution interacting with silver NPs covered by a polymer shell of variable thickness [10]. The best 2-fold fluorescence enhancement has been observed for the $16 \mathrm{~nm}$ thick polymer shell. Theoretical description of the system predicts that more than 20 -fold enhancement of $J$-aggregates fluorescence could be expected under optimal conditions [10]. For further progress in this direction, the obtained results should be compared with that for MEF studying the TC monomer interaction with silver NPs. So, this work we have investigated MEF of thiacyanine dye monomers via interaction with $\mathrm{Ag}$ NPs in polyelectrolyte films of a tunable size.

\section{Experimental part}

Thiacyanine dye TC (3,3'-diethyl-thiacyanine bromide, Fig. 1a) was synthesized by Dr.I.A.Borovoy with purity controlled by NMR and thin layer chromatography. To prepare TC monomers aqueous solution, the dye was dissolved in doubly-distilled water with a concentration $10^{-3} \mathrm{M}$ and ultrasonicated for $15 \mathrm{~min}$. Cationic polyelectrolyte PDDA (poly(diallyldimethylammonium chloride), average $M_{w}<100000 \mathrm{~g} / \mathrm{mol}$, solution 35 wt. $\%$ in $\mathrm{H}_{2} \mathrm{O}$, Fig. $1 \mathrm{~b}$ ) and anionic polyelectrolyte PSS (polysodium 4-styrenesulfonate), average $M_{w} \sim 70000 \mathrm{~g} / \mathrm{mol}$, powder, Fig. 1c) were purchased from Sigma Aldrich (USA) and used as-received.

Silver nanoparticles were obtained using citrate ion reduction method [11] from silver nitrate water solution purchased from Sigma Aldrich (USA). As a result, spherical nanoparticles were obtained with the average diameter of about $50 \mathrm{~nm}$ and the maximum of plasmonic resonance at around $410 \mathrm{~nm}$ in water (Fig. 2a, curve 3).

To prepare polymer films containing TC monomers, the spray layer-by-layer assembly method [12] has been applied. For this purpose commercially available paintbrush 80-897 (Miol, China) has been used. A substrate glass plate was preliminarily cleaned by hot $\left(95^{\circ} \mathrm{C}\right)$ piranha acid $\left(\mathrm{H}_{2} \mathrm{SO}_{4}+\mathrm{H}_{2} \mathrm{O}_{2}\right.$ $=2: 1$ ). Cleaning by the piranha acid gives a negatively charged surface of the glass. Then, an aqueous polycation PDDA solution (2 wt. \%) was sprayed on the substrate for coating by a positively charged film (Fig. 3). After that, the aqueous Ag NPs<smiles>CCCCCCCCN1/C(=C/c2sc3ccccc3[n+]2CC)Sc2ccccc21</smiles>

b)<smiles>CC(C)(C)CC1C[N+](C)(C)CC1CC(C)(C)C</smiles>

c)<smiles>[Y]C(CC(C)(C)C)c1ccc(S(=O)(=O)[O-])cc1</smiles>

Fig. 1. The chemical structures of the TC dye (a) and polyelectrolytes PDDA (b) and PSS (c).

solution was sprayed, as Ag NPs is coated by a negatively charged citrate shell. Then a PDDA layer was deposited on the Ag NPs layer with successive deposition of a negatively charged polymer layer from an aqueous polyanion PSS solution (2 wt. \%) (Fig. 3). As TC dye is the cationic one (Fig. 1a) the layer was deposited on the PSS layer or directly on the Ag NPs layer in case of minimal distance between Ag NPs and TC monomers. To control the distance between NPs and the dye PDDA and PSS layers were alternated. The monomers layer was coated by PDDA layer to provide isolation from surrounded air (Fig. 3). Each layer deposition was followed by rinsing sprayed distilled water.

Fluorescence spectra of the polymer films were obtained using fluorescent microscope MIKMED-2 var.11 (LOMO, Russia) coupled with microspectrometer USB4000 (OceanOptics, USA) via a home-made fiberoptic adapter attached to the $20 \mathrm{X}$ eyepiece. Spectral output of the microspectrometer USB4000 was calibrated using calibrated tungsten halogen lamp HL-2000-CAL (OceanOptics, USA). Fluorescence was excited at 385-425 $\mathrm{nm}$ and collected in the 455-700 $\mathrm{nm}$ spectral range using violet filter set (11005v2, Chroma, USA). Absorption spectra were registered using a spectrophotometer USB4000 (Ocean Optics, USA) supplied with an incandescent lamp. Fluorescence decay spectra were registered using FluoTime 200 fluorescence lifetime spectrometer (PicoQuant, Germany) equipped with picosecond pulsed laser diode head 

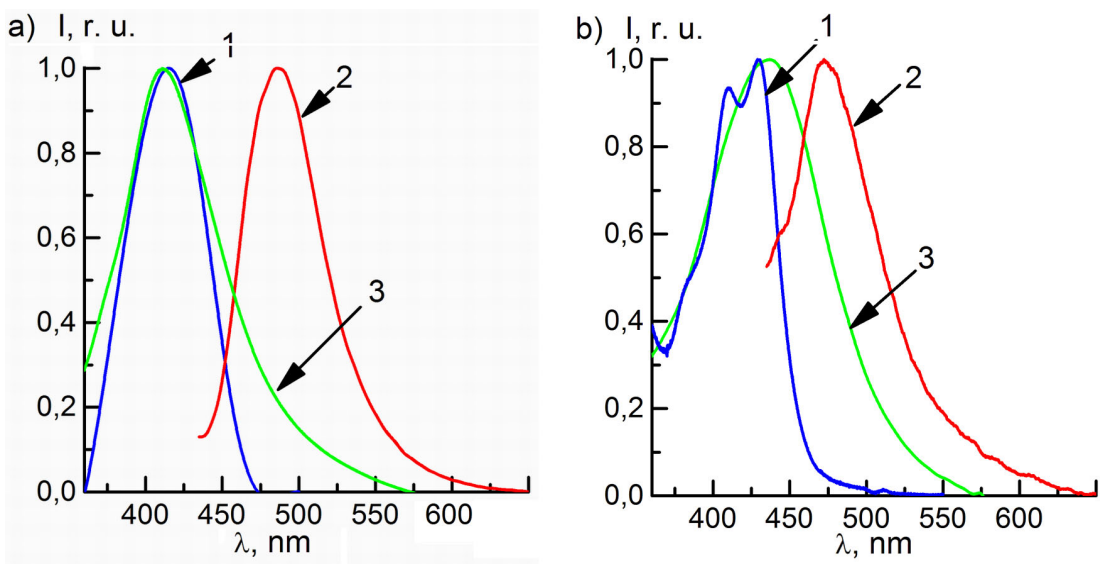

Fig. 2. Absorption (1) and fluorescence $\left(\lambda_{e x c}=420 \mathrm{~nm},(2)\right.$ spectra of TC dye and the Ag NPs absorption spectrum (3) in different media: a) water, b) LbL film.

$\left(\lambda_{\text {em }}=439 \mathrm{~nm}\right)$. An instrument response function (IRF) width for the whole setup was 100 ps. A solid sample holder was used to provide front face illumination. For decay curves analysis FluoFit software (PicoQuant, Germany) was used.

\section{Results and discussion}

It is known that a dye aggregation is promoted by interaction with water molecules first of all due to hydrophobic forces involved [13]. Besides, incorporation of cyanine dyes into polymer films by layer-bylayer assembly method used in the present work results in further promotion of aggregation process [14]. According to [15], J-aggregation ability of thiacyanine dyes strongly dependends on $5,5^{\prime}$-substitutes of the chromophore (Fig. 1a). Chlorine substitutes promote the $J$-aggregation while hydrogen substitutes inhibit aggregation and the dye presents in an aqueous solution in a monomeric state or as H-dimers [15]. So, in the present study cationic form of the thiacyanine dye without specific 5, $5^{\prime}$-substitutes has been used (Fig. 1a).

Monomeric TC dye absorbs and emits a light at shorter wavelength comparing with classical cyanines [16] with $\lambda_{a b s} \mathrm{DMF}=$ $432 \mathrm{~nm}$ and $\lambda_{e m} \mathrm{DMF}=485 \mathrm{~nm}$ in dimethylformamide (DMF) (not shown, see [10]). In the aqueous solution its absorption band is blue-shifted compared with TC in DMF with $\lambda_{\text {abs }}$ water $=414 \mathrm{~nm}$ while spectral position of the fluorescence band remains unchanged (Fig. 2a). There are two main reasons for the dye blue shift: solvatochromic effect [17] and H-dimerization of TC in water [15]. The latter is proved by near symmetrical shape of the absorption band without pro-

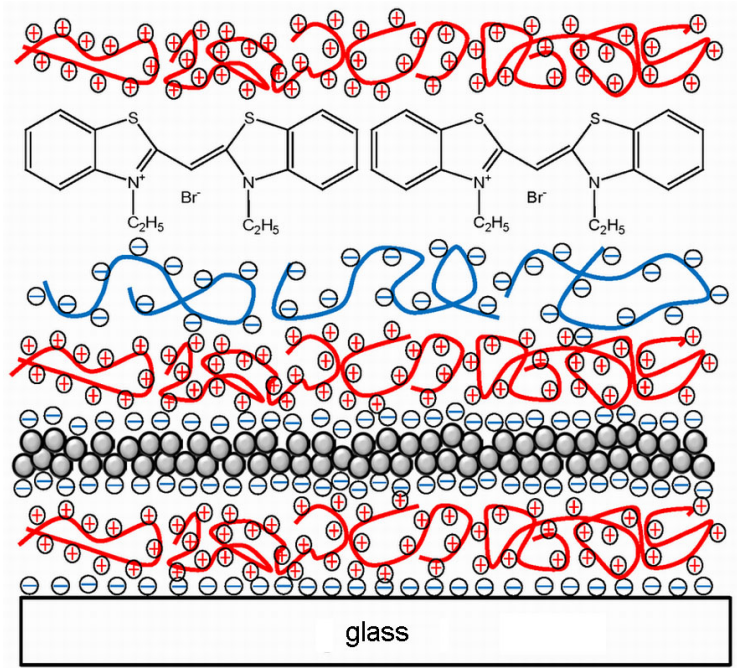

Fig. 3. Scheme of hybrid composite film with controlled thickness of the spacer between the dye and Ag NPs layers.

nounced shoulder of vibrational band and the absence of the fluorescence band shift (Fig. 2a, curve 1). Due to the absorption band $\left(\lambda_{p l}\right.$ water $\left.=410 \mathrm{~nm}\right)$ of the plasmon resonance of Ag NPs perfectly coincides with the absorption band of TC dye (Fig. 2a) the effective MEF should be expected [5].

To control the distance between silver NPs and TC dye molecules, a method of oppositely charged polyelectrolyte layers alternation known as layer-by-layer (LbL) assembly has been used [18]. LbL method was successfully applied for the fluorescence enhancement of sulforhodamine B by interaction with silver islands [6]. Modification of LbL method for colloid solutions has been used also in our previous research [10]. According to the literature data the thickness of the LbL polymer layers is about $1.5 \mathrm{~nm}$ 

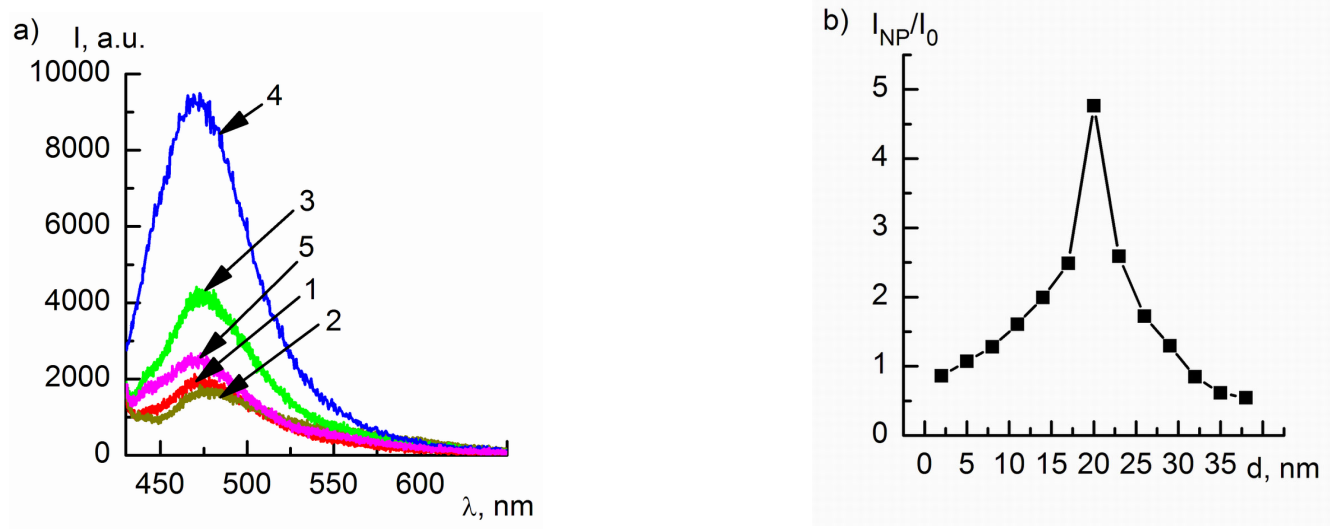

Fig. 4. a) Fluorescence $\left(\lambda_{\text {exc }}=420 \mathrm{~nm}\right)$ spectra of TC monomers depending on the spacer thickness: 1 - without Ag NPs, 2 - the dye directly on NPs, $3-5$ bilayers, $4-6$ bilayers, $5-9$ bilayers. b) The effect of the distance between the dye and Ag NPs layers on the TC fluorescence enhancement.

$[6,10,18]$. So, we prepare TC-Ag NPs composite films with the dye and NPs layers separated by different amount of PSSPDDA bilayers from 0 to 12 (Fig. 3) and analyze TC dye fluorescence properties.

Embedding into polymer films results in shifting the spectral bands of all optical species (Fig. 2b). In the TC absorption spectrum two intense bands could be resolved: one with maximum at $\lambda_{\text {abs }}$ film $=429 \mathrm{~nm}$ and the second one with maximum at $\lambda_{a b s}$ film $=$ $410 \mathrm{~nm}$ (Fig. 2b, curve 1). The first band corresponds to the band observed in DMF and it could be associated with the monomeric main electronic transition. The second band corresponds to the band observed in water (Fig. 2a, curve 1) and it could be associated with overlap of the vibronic band and the $\mathrm{H}$-band as its intensity is too high to be the vibronic band only [15]. The fluorescence band (Fig. 2b, curve 2) is blue-shifted with $\lambda_{\text {em }}$ film $=472 \mathrm{~nm}$ due to the solvatochromic effect [18]. The plasmonic band (Fig. 2b, curve 3) of Ag NPs with $\lambda_{p l}$ film $=437 \mathrm{~nm}$ is appeared to be redshifted obviously due to agglomeration of NPs but it still coincides with the TC absorption band in a good manner.

So, composite system consisted of $\mathrm{LbL}$ polymer films, Ag NPs and TC dye is suitable for MEF study. When TC dye is deposited directly on silver NPs layer strong fluorescence quenching is observed according to the MEF theory [1-6]. Distance increasing between the dye and NPs results in the fluorescence enhancement but only to some critical distance (12 polymer layers in our case) with following fluorescence decrease at the distances exceeded the critical one (Fig. 4a). For illustration purposes the fluorescence enhancement has been represented as a plot of the fluorescence intensities (at $\lambda_{\text {em }}$ film $=472 \mathrm{~nm}$ ) ratio of TC fluorescence separated from Ag NPs by a certain thickness spacer to TC fluorescence in absence of $\mathrm{Ag}$ NPs versus the thickness of the polymer spacer (Fig. 4b). The latter is defined as the layers amount in the spacer multiplied by $1.5 \mathrm{~nm}$ thickness of each layer plus $2 \mathrm{~nm}$ thickness of Ag NPs citrate coating [10]. From the plot it could be seen that about 5 -fold (4.75-fold in the strict sense) enhancement of TC fluorescence has been achieved at $20 \mathrm{~nm}$ distance between TC dye layer and Ag NPs layer (Fig. 4b).

Another way to carry out MEF study is analysis of the dye lifetime changing due to interaction with metal NPs [6]. Electronplasmon interaction results in radiative decay rate increasing, i.e. at the maximal fluorescence enhancement the minimal lifetime should be achieved [6]. Indeed, the distance between NPs and TC increasing up to the critical one leads to the lifetime shortening down to the minimal value with followed restoring up to initial values (Fig. 5a). Note that in all cases TC fluorescence decay curves have non-monoexponential shape with average lifetimes $\tau_{0}=360$ ps (in absence of NPs) and $\tau_{\mathrm{NP}}{ }^{\text {min }}=86$ ps (at the maximal fluorescence enhancement). As previously the lifetimes changing has been plotted as the dependence of lifetimes in NPs absence and NPs presence ratio versus the distance between NPs and the dye (Fig. 5b). The maximal lifetime decreasing has been about 4 -fold (4.25-fold in the strict sense) at the same $20 \mathrm{~nm}$ distance between NPs and the dye. Interesting that in the case of MEF for sulforhodamine $B$ the most effec- 

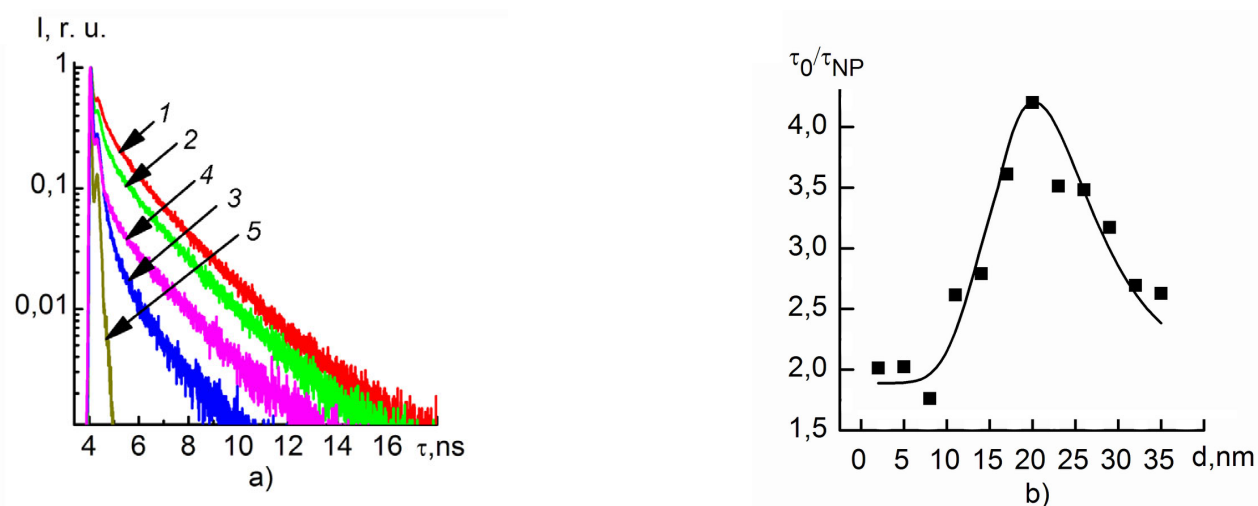

Fig. 5. a) Fluorescence decay curves $\left(\lambda_{e x c}=438 \mathrm{~nm}, \lambda_{\text {reg }}=470 \mathrm{~nm}\right)$ of TC monomers depending on the spacer thickness: 1 - without Ag NPs, 2 - the dye directly on NPs, $3-6$ bilayers, $4-$ 12 bilayers, 5 - IRF. b) The effect of the distance between the dye and Ag NPs layers on the TC lifetime decreasing.

tive fluorescence enhancement was about 6 fold on the $10 \mathrm{~nm}$ distance with strong difference between the steady-state and timeresolved fluorescence changing [6]. Taking into account experimental errors and the similarity of the stationary fluorescence and the lifetime measurement data (Fig. $4 \mathrm{~b}$ and 5 b) we could conclude the average 4.5 -fold fluorescence enhancement of TC dye by Ag NPs on the distance of $20 \mathrm{~nm}$ between them. Comparing with only 2 -fold TC $J$-aggregate fluorescence enhancement by $\mathrm{Ag}$ NPs on the distance of $16 \mathrm{~nm} \mathrm{[10]} \mathrm{we} \mathrm{as-}$ sume a very effective MEF achieved in the obtained hybrid system based on TC monomers.

\section{Conclusions}

The metal enhanced fluorescence of thiacyanine dye monomers has been studied by the distance controlled interaction with silver nanoparticles. For the distance control, the layer-by-layer assembly of PSS and PDDA polyelectrolytes has been used. Both the steady-state and time-resolved fluorescence changing depending on the spacer thickness between the dye and NPs has been analyzed. Maximal 4.5-fold fluorescence enhancement of TC has been found at the distance of about $20 \mathrm{~nm}$ between nanoparticles surface and the dye.

\section{References}

1. M.I.Stockman, Opt.Express, 19, 22029 (2011).
2. M.I.Stockman, Phys. Today, 64, 39 (2011).

3. V.V.Klimov, Phys.Usp., 51, 839 (2008).

4. Metal-Enhanced Fluorescence, ed. by Ch.D.Geddes, John Wiley \& Sons. Inc., Hoboken, New Jersey (2010).

5. T.Ming, H.Chen, R.Jiang et al., J.Phys.Chem. Lett., 3, 191 (2012).

6. K.Ray, R.Badugu, J.R.Lakowicz, Chem. Mater., 19, 5902 (2007).

7. P.Anger, P.Bharadwaj, L.Novotny, Phys.Rev. Lett., 96, 113002 (2006).

8. S.Kuhn, U.Hakanson, L.Rogobete, V.Sandoghdar, Phys. Rev. Lett., 97, 017402 (2006).

9. K.Ray, R.Badugu, J.R.Lakowicz, Chem. Mater., 19, 5902 (2007).

10. A.V.Sorokin, A.A.Zabolotskii, N.V.Pereverzev et al., J.Phys. Chem. C, 118, 7599 (2014).

11. Z.S.Pillai, P.V.Kamat, J.Phys.Chem.B, 108, 945 (2004).

12. A.Izquierdo, S.S.Ono, J.-C.Voegel et al., Langmuir, 21, 7558 (2005).

13. F.Wurthner, T.E.Kaiser, Ch.R. Saha-Muller, Angew.Chem.Int.Ed., 50, 3376 (2011).

14. H.Fukumoto, Y.Yonezawa, Thin Solid Films, 327-329, 748 (1998).

15. C.Peyratout, L.Daehne, Phys.Chem.Chem. Phys., 4, 3032 (2002).

16. A.Mishra, R.K.Behera, P.K.Behera et al., Chem. Rev., 100, 973 (2000).

17. J.R.Lakowicz. Principles of Fluorescence Spectroscopy, 3rd ed., Springer, Singapore (2006).

18 G.Decher, Science, 277, 1232 (1997). 